\author{
KESJÁR Szilvia, \\ BALSA-BUDAI Nikolett, \\ SOÓS Mibály \\ Debreceni Egyetem \\ Gazdaságtudományi Kar \\ Marketing és Kereskedelem Intézet \\ University of Debrecen, \\ Faculty of Economics and Business, \\ Institute of Marketing and Trade \\ H-4032 Debrecen, Böszörményi út 138. \\ kesjar.szilvia@gmail.com
}

\section{KOLBÁSZFOGYASZTÁSI SZOKÁSOK VIZSGÁLATA MAGYARORSZÁGON}

\author{
THE EXAMINATION OF CONSUMPTION PATTERNS \\ OF SAUSAGES IN HUNGARY
}

\begin{abstract}
Appropriate nutrition and qualitative food have played an ever bigger role in the recent years. At the same time, pork meat stands in the middle of many discussions on account of medical judgement. Pork meat and the products of pork meat are popular in Hungarian nutrition. In our country the tradition of pig breeding and pig slaughter - especially in villages and smaller settlements has been present decidedly. We all know that many of us like it, but do we know what kind of sausage Hungarian people like the most, on what basis they choose, how much money they spend, how often they eat and where they pick the information up about the Hungarian sausages? The goal of the study is to get a wider perspective about the consumption patterns of Hungarian people, helping the work of the market players who deal with sausage making and sale, and they would like to know the demand, opinion and criterion of decisions of the potential customer. Regarding the methodology, we have choosen the online questionnaire, in which 690 members took part. The questionnaire is representative with regard to sex, in addition several answers have come from all regions of our country.
\end{abstract}

Keywords: sausage consumption, consumer behaviour, meat consumption, nutrition

JEL codes: Di2, L83

\section{BEVEZETÉS}

Mi, magyarok le sem tagadhatjuk, hogy kolbászfogyasztó nép vagyunk. A lakosság körében elterjedt a szófordulat, mindenki tudja, miről van szó, és nagy részük fogyasztja is ezt a különleges, többnyire sertéshúsból készült terméket.

Azt felismervén, hogy a kolbász a magyarok kultúrájában, táplálkozásában és hagyományaiban lényeges szerepet tölt be, napjainkra egyre erősödnek a nagyobb, húskészítmények előállításával foglalkozó üzemek és gyárak, valamint a kisebb, esetenként hagyományos eljárásokkal tevékenykedő egyéni, családi vagy társas vállalkozások.

Ennek ellenére a sertéshúshoz negatív előítéletek társulnak, a hazai fogyasztók szerint a vörös húsok - közülük is a sertéshús nem tartoznak a korszerű étkezéshez, aminek oka magas zsír- és koleszterintartalmuk (Szente, 2010). Az ilyen és ehhez hasonló táplálkozási dilemmák voltaképpen a táplálkozási ajánlások ellentmondásaira épülnek (Szakály, 2004), a fogyasztók számára pedig nehéz a különböző, más-más forrásokból szerzett, ellentétes információkat megfelelően szürni és kezelni.

Tovább nehezíti a helyzetet az új piaci szereplők megjelenése és a kínálati oldal felhígulása. Miután a Gyulai és Csabai kolbász hungarikum, ezt megragadva az utóbbi években egyre több szereplő lépett be a piacra, és már nehéz kiválasztani a minőségi terméket a hatalmas választékból. A kolbászok piacán is fellépett az a probléma, hogy a termékeket a vonzóbb megítélés vagy a hosszú távú eltarthatóság miatt sok esetben szükségtelen mesterséges adalékanyagokkal látják el, továbbá a nagyobb haszon elérése érdekében liszttel és szójával dúsítják a termékeket.

A kínálati oldal szereplői közül akármely csoportot vizsgáljuk, ritkán ismerik a vevőkört, a potenciális fogyasztókat és azok elvárásait. Gyakran nincsenek tisztában a termékeikre szánt összeggel, a fogyasztás gyakoriságával, illetve nem tudják, vásárlóik mi alapján döntenek egyes kolbászok mellett vagy ellen. A nem megfelelő marketingstratégia egyik oka lehet a keresleti oldal hiányos ismerete.

\section{I+I. Húsfogyasztás Magyarországon - különös tekintettel a sertéshúsra}

Hazánkban a háztartások költéseinek legnagyobb részét (az összes költés mintegy negyedét) az élelmiszer-kiadások teszik ki (Kozák, 2009). A baromfihús mögött kevéssel lemaradva a sertéshús a másik leggyakrabban vásárolt húsféle, valamint külön kategóriaként megjelenik a szalámi, kolbász, sonka kategória is (KSH, 20I6). 
Egy másik, 2013-ban végzett felmérés alapján pontosabb képet kaphatunk az érintett területről. Az 1. ábrán látható, hogy a megkérdezettek közül a legtöbben a sertéshúskészítmények közül a kolbászt fogyasztják. A vásárlások során itt is hangsúlyos a termék minősége, illetve fiatalabb korosztályok esetén az ár nagy hatással van a vásárlási döntésre. A védjegyeknek a termék vásárlásakor nincs meghatározó szerepe a többi tényező figyelembe vétele mellett, viszont a védjeggyel jelölt termékek felé nagyobb bizalommal fordulnak a fogyasztók. A minőséget szavatoló védjegy esetében a válaszadók 8\%-kal magasabb árat hajlandók fizetni a termékekért. Ezenfelül a hazai terméket előnyben részesítik a fogyasztók jó minőségük és megbízhatóságuk miatt, valamint a hazai gazdaság támogatása érdekében. A hazai sertéshús-eloaállítók megnevezése kapcsán a válaszadók több mint fele ismeri a Pick márkát, majd ezt követi sorban a Gyulai Hús, a Pápai Hús és a Csabahús (IPSOS, 2013).

\section{I. ábra: Sertéshúskészítmények fogyasztása a megkérdezettek körében}

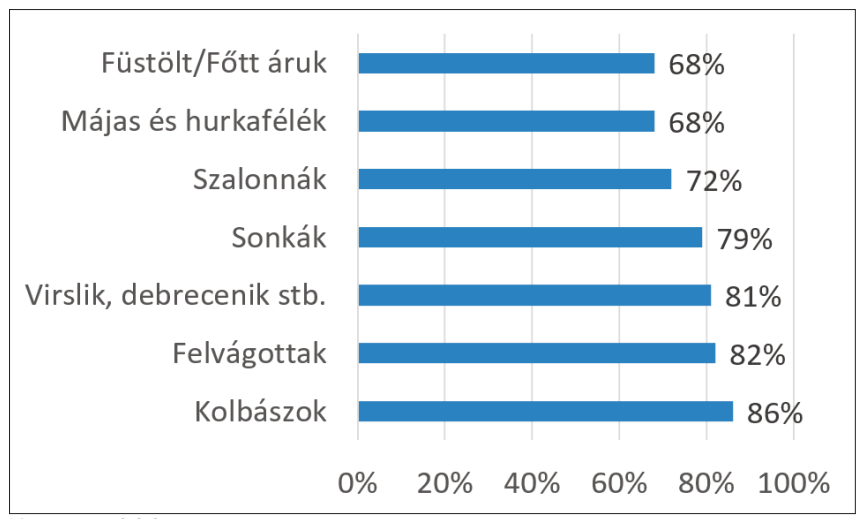

Forrás: IPSOS, 2013

A kutatási eredményeket nézve pozitív a sertéshús helyzete Magyarországon. Kedvelt húsfajta, és gyakran fogyasztja a lakosság nagy része nemcsak frissen, de feldolgozott formában is. Ezek az adatok mindenképp kedveznek a kolbászok helyzetének is, hiszen a magyar kolbász - köztudottan - fóként sertéshúsból készül. Bizonytalanságra ad okot azonban az egészségtudatos fogyasztói magatartás előtérbe kerülése és a sertéshús negatív egészségügyi megítélése között húzódó ellentét.

\section{I+2. Sertéshúsfogyasztással kapcsolatos táplálkozási dilemmák}

"A táplálkozás egyre inkább az egészség erősítésének és a betegségek megelőzésének lényeges eszközévé válik, túlmenően az alapvető táplálkozás-élettani jelentőségén" (Bíró, 2007). Ám az egészség és egészséges táplálkozás fogalmát vizsgálva dilemmákba ütközünk.

A táplálkozási dilemmák voltaképpen a táplálkozási ajánlások ellentmondásaira épülnek (Szakály, 2004; Soós E Szakály, 2013), a fogyasztók számára nehéz a különböző, más-más forrásokból szerzett, ellentétes információkat megfelelően szürni és kezelni, ezért bizonytalanok az ismereteik a fogyasztóknak ezen a területen (Szakács, 2012).

A sertéshúst gyakran kritizálják meglehetősen magas zsír- és koleszterintartalmának köszönhetően (Várhegyi \& Várhegyi, 2007), pedig maga a sertéshús nem magasabb zsírtartalmú, mint más állatok húsa.
Sokkolta a világot a WHO azon jelentése, melyben a vörös húsok rákkeltő hatását fejtegeti. A szervezet abban hibázott nagyot, hogy a sok kockázati tényezőt nem azonos mértékben kezelte, kiemelte közülük a vörös húsok fogyasztását, mint a rák kialakulásának magas kockázatokkal járó forrását. Későbbiekben a WHO egyik munkatársa úgy nyilatkozott, hogy kicsi az esélye annak, hogy csupán a vörös húsok fogyasztása rákot okoz, de minél többet fogyaszt belőle az illető, annál nagyobb a kockázat (Népszava, 20I6).

A fogyasztók képesek összekeverni a sertéshús fogyasztása miatt kialakult megbetegedéseket a túlzott fogyasztásból eredő kedvezőtlen táplálkozás-élettani hatásokkal, amelyek közvetve fejtik ki egészségkárosító hatásukat. Vida tanulmányában számos példán keresztül szemlélteti a különböző rákkutatással foglalkozó szakemberek által közölt publikációkat. Az eredményeket végigolvasva egyetértünk azzal a megállapítással, miszerint nem hozható egyértelmű összefüggésbe a sertéshús fogyasztása és bármely rákos megbetegedés kialakulása. Sokat számít a hús minősége, elkészítésének módja, valamint a feldolgozása során használt adalékanyagok milyensége (Vida, 2012).

Zsarnóczay szerint nincs jó vagy rossz étel, hiszen az ételféleségek tápanyag-összetétele különböző. Az egyoldalú étrend nem megfelelö, hiszen önmagában egyik ételféleség sem tartalmazza a szervezetünk egészséges működéséhez szükséges összes tápanyagot. Az egészség megőrzéséhez és a jó erőnléthez I 3 féle vitamin, I6 féle ásványi anyag, emellett zsírok, fehérjék és szénhidrátok szükségesek. Mindenképp a változatos étkezés elvét kell követnünk, hogy az összes tápanyag optimális mértékben jusson a szervezetünkbe (Zsarnóczay, 2009).

\section{1+3. Adalékanyagok a húskészítményekben}

Egyre nagyobb vita középpontjában áll a hústermékek és -készítmények előállításánál használt mesterséges adalékanyagok, ízesítőszerek, színezékek és állományjavítók nagymértékü felhasználása. Ennek oka az lehet, hogy a modern élelmiszeripari technológiának köszönhetően sok esetben adnak a termékhez adalék - és egyéb segédanyagokat. Ezek egy része valóban a termék tulajdonságainak javítását szolgálja, és egészségügyi kockázatuk jelenleg nem ismert (Vida, 2012).

Zsarnóczay tanulmányában azt fogalmazta meg, hogy ezek az adalékanyagok többnyire a kereskedő, a vásárló és a fogyasztó biztonságát szolgálják, hiszen a hütés nem nyújt megfelelő védelmet, és a termék idővel veszít tápanyagértékéből, friss érzetéből és kívánatos megjelenéséből (Zsarnóczay, 20I I).

Ezzel ellentétben Szakály kutatásában jól látható, hogy a megkérdezettek leginkább az E-számokat és a koleszterint, valamint a tartósítószereket tartják a legveszélyesebbnek az élelmiszerek és élelmiszer-összetevők közül (Szakály, 2008). Ezeket az eredményeket megerősíti a Gál, Soós és Szakály által 20I7-ben elvégzett kutatás is (Gál, Soós E Szakály, 2017). A sort követi igen magas értékkel a magas sótartalmú és magas cukortartalmú ételek csoportja, az állományjavítók és a színezékek.

\section{ANYAG ÉS MÓDSZER}

A kutatás során a szekunder információforrások összegyüjtését követően primer kutatás is történt. Adatgyüjtés szempontjából kvantitatív információkat választottunk, mivel célunk az volt, hogy minél megbízhatóbb és pontosabb, számszerűsíthető adatokat 
kapjunk. Ennek értelmében kérdőíves megkérdezés alkalmazásával kerestünk választ az általunk megválaszolni kívánt kérdésekre, valamint az ebből fakadó eredményeink alapján értékeltük a témában szerzett adatokat.

A fogyasztói oldal felmérésében online kérdőives megkérdezést alkalmaztunk. A mintavétel során 690 db kérdőív került kitöltésre az ország különböző régióiban. $\mathrm{Az}$ eredmények a válaszadók nem szerinti megoszlása tekintetében reprezentatívak az országos népesség férfi-nő megoszlásához viszonyítva, régiók tekintetében pedig elemezhető mennyiségü elemszámmal rendelkeznek az összevetésekhez (minimum 77 fö/régió). A minta összetételét az 1. táblázat mutatja.

I. táblázat: A kérdőiv háttérváltozóinak összefoglaló táblázata $(\mathrm{N}=690)$

\begin{tabular}{|c|c|c|}
\hline Szocio-demográfiai változók & Fó & $\%$ \\
\hline \multicolumn{3}{|c|}{ Nem } \\
\hline Férfi & 298 & 43,19 \\
\hline Nő & 392 & $56,8 \mathrm{I}$ \\
\hline \multicolumn{3}{|c|}{ Kor } \\
\hline I $8-25$ & 309 & 44,78 \\
\hline $26-35$ & 195 & 28,26 \\
\hline $36-45$ & 83 & I 2,03 \\
\hline $46-55$ & 72 & Io,43 \\
\hline $56-65$ & 26 & 3,77 \\
\hline $66<$ & 5 & 0,72 \\
\hline \multicolumn{3}{|c|}{ Lakóhely/régió } \\
\hline Észak-Magyarország & 90 & I3,04 \\
\hline Észak-Alföld & II6 & I6,8I \\
\hline Dél-Alföld & 120 & I7,39 \\
\hline Közép-Magyarország & 90 & I3,04 \\
\hline Közép-Dunántúl & 77 & II,I6 \\
\hline Nyugat-Dunántúl & 95 & I3,77 \\
\hline Dél-Dunántúl & 86 & I 2,46 \\
\hline Egyéb/Külföld & I6 & 2,32 \\
\hline
\end{tabular}

Az adatelemzés az SPSS matematikai-statisztikai elemző szoftverrel történt, amely segítségével a gyakorisági megoszlás mellett kereszttáblás elemzéseket, szignifikanciavizsgálatot, valamit átlag- és szórásvizsgálatot is alkalmaztunk. Az eredmények között törekedtünk arra, hogy a háttérváltozókkal történt kereszttáblás elemzések eredményei közül csak a szignifikánsakat $(\mathrm{p} \leq 0,05)$ mutassuk be.

\section{EREDMÉNYEK ÉS AZOK ÉRTÉKELÉSE}

Ebben a fejezetben az előző szakaszban bemutatott módszerek segítségével értékeljük eredményeinket, melyek közül csak a legszámottevőbbeket emeljük ki, így a kolbászfogyasztás gyakoriságára és rendszerességére, a termékszerkezet- és választékelemzésre, a vásárlási döntést befolyásoló tényezőkre, a termék táplálkozásélettani szerepére, a kolbászvásárlás körülményeire, valamint a médiahasználati szokásokra térünk ki.

\section{3+I. Kolbászfogyasztási szokások}

Eredményeink alapján a megkérdezettek túlnyomó többsége (89,7\%) fogyaszt kolbászt. A háttérváltozókkal végzett szignifikanciavizsgálatból arra lehet következtetni, hogy összefüggés van a kolbászt fogyasztók és nem fogyasztók, valamint a lakóhelyeik (régiók) között.
A Dél-Alföld, Észak-Alföld és Észak-Magyarország lakosai jelölték a legnagyobb százalékban igennel az adott kérdésre a választ, míg a Közép-Dunántúlon élők közül válaszoltak a legtöbben nemmel. Ebben a régióban a válaszadók 22,I\%-a nem fogyaszt kolbászt, míg a többi régióban ez a válasz egységesen $\mathrm{I} 2,0 \%$ alatti. A 2. ábrán látható a kolbászféleségek fogyasztásának rendszeressége.

2. ábra: A kolbászfogyasztás rendszeressége, \% (N = 6I9)

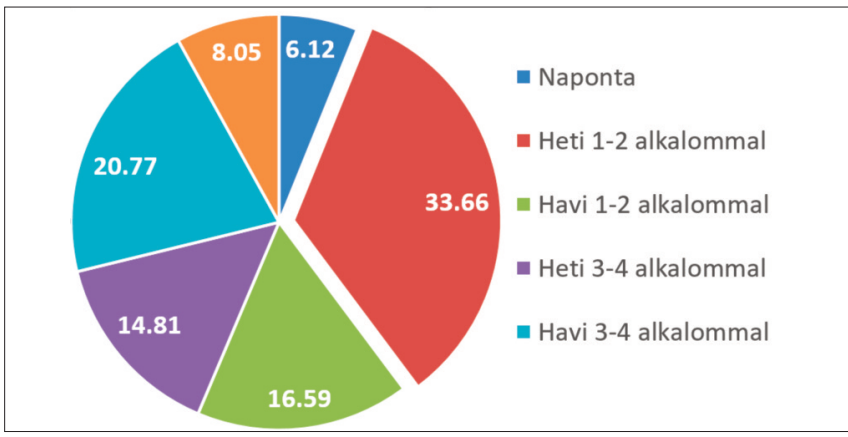

A megkérdezettek több mint fele legalább heti I-2 alkalommal vagy annál sürübben fogyaszt kolbászt, és csupán 8,0\%-uk ritkábban, mint havonta. Az ábrán az elkülönített körcikk megmutatja, hogy a válaszadók többsége (33,6\%-a) heti I-2 alkalommal fogyaszt kolbászféléket. Férfiak és nők tekintetében a férfiak a két leggyakrabban fogyasztó kategóriában nagyobb százalékban vannak jelen.

A nemen kívül a kor is összefüggésbe hozható a kolbászfogyasztás gyakoriságával. A naponta fogyasztók között legnagyobb arányban a 36-45 éves korcsoport szerepelteti magát $(8,4 \%)$, míg a heti 3-4 alkalommal fogyasztók között a 36-45 éves korcsoport (I6,9\%) mellett a $46-55$ éves korcsoport $(23,6 \%)$ is magas arányban szerepel.

A kolbászfogyasztás gyakorisága és a válaszadó lakóhelye (régió) között is szoros kapcsolat fedezhető fel. A naponta fogyasztók legmagasabb százalékban a Nyugat-Dunántúlon élnek (9,5\%), őket követik a Dél-Alföld és Közép-Magyarország válaszadói (mindkettő 6,7\%). A második leggyakrabban fogyasztó kategóriában - azaz a heti 3-4 alkalommal fogyasztók között - a Dél-Alföld (2I,7\%), kissé lemaradva tőlük a Nyugat-Dunántúl (I6,8\%) lakói szerepeltek legnagyobb százalékban.

\subsection{A kolbásszal kapcsolatos termékszerkezet- és választékelemzés}

A következő részben a lakosság ízlését mértük fel a kolbászokra vonatkozóan. Az 3. ábrán látható a kolbászok kedveltségének alakulása ízükre vonatkozóan.

3. ábra: A kolbászok ízeinek kedveltsége, \% (N = 619)

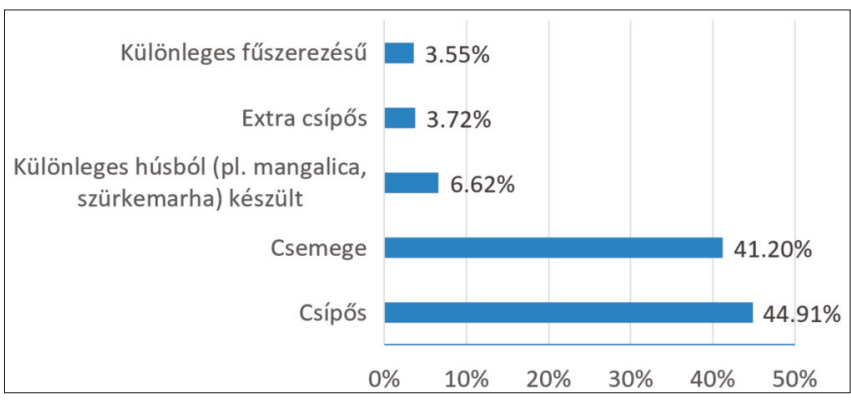


Megfigyelhető, hogy a csemege (4I,2\%) és a csípős (44,9\%) kolbász szinte ugyanolyan mértékben kedvelt a megkérdezettek alapján, és csak nagyon kis arányban kedvelik leginkább a különleges vagy nagyon csípős kolbászokat. Nemek tekintetében a csípős, extra csípős és különleges füszerezésü kolbászok a férfiak által kedveltebbek, ám a csemege kolbászoknál a nők aránya magasabb (4I,8\%).

Régiók szerinti vizsgálat alapján a csemegekolbászt legnagyobb arányban az Észak-Alföldön (44,8\%) és az Észak-Magyarországon (44,4\%) élők választották elsősorban, míg a csípős kolbász a DélAlföldön magasan a legkedveltebb (57,5\%). A vizsgálatok szerint az extra csípős kolbászt a nyugat-dunántúli régióban élők kedvelik leginkább (9,5\%), de Dél-Alföld is magas százalékkal szerepel ebben a kategóriában $(5,8 \%)$. A különleges húsból készült kolbászokat a Dél-Dunántúlon (I0,5\%) és a Közép-Magyarországon $(8,9 \%)$ lakók jelölték legmagasabb százalékban, mint általuk legkedveltebb kategória.

\section{3+3. Kolbászvásárlási döntések}

A következő kérdések a fogyasztók kolbászvásárlási döntéseire irányultak, melyek eredményei a 2. táblázatban tekinthetők meg.

\section{2. táblázat: Kolbászvásárlási döntésekkel kapcsolatos állítások}

$$
(\mathrm{N}=619)
$$

\begin{tabular}{|c|c|c|}
\hline Állitás & Átlag & Szórás \\
\hline $\begin{array}{c}\text { Ha megszeretem egy kolbász ízét, inkább azt } \\
\text { vásárolom, de ha elnyeri a tetszésem egy másik fajta, } \\
\text { megveszem és megkóstolom. }\end{array}$ & 3,96 & 0,90 \\
\hline $\begin{array}{c}\text { Ha megszeretem egy kolbász ízét, attól fogva azt kere- } \\
\text { sem és vásárolom. }\end{array}$ & 3,87 & $\mathrm{I}, 03$ \\
\hline Inkább szeretek új ízeket kipróbálni. & 2,93 & I,IO \\
\hline
\end{tabular}

Megjegyzés: Az eredményeket I-től 5 -ig terjedő végpontskálán értelmezzük, ahol I = Egyáltalán nem, 5 = Teljes mértékben.

Az első állítás 3,96-os átlageredménnyel inkább jellemző a sokaságra. Eszerint a megkérdezettek márkahüsége meglehetősen magas a kolbászokat illetően, bár egy új termék hatására meg tudnak válni a korábban folyamatosan vásárolt fajtától.

A második állítás, amely kifejezetten a kolbászvásárlások alkalmával kialakult márkahüségre vonatkozik, hasonló eredményt mutat. A megkérdezettek nagyobb arányban inkább márkahűnek mondhatók. Ebben a kérdésben a nők 3,97-es átlagértékkel válaszoltak az I-5 skálán, vagyis a nők jobban ragaszkodnak egy már bevált termékhez, mint a férfiak. Korosztály tekintetében az érték növekvő tendenciát mutat: míg a I 8-25 évesek átlagértéke erre a kérdésre 3,73 lett, az 56-65 éves korosztálynál ez az érték már eléri 4,22-t. Tehát minél idősebb a vásárló, annál inkább ragaszkodik a bevált ízekhez, fiatalabb korban pedig szívesebben kísérleteznek, nem ragadnak le egy terméknél a fogyasztók. Régiókat vizsgálva a dél-alföldi régióban lakó válaszadók a leginkább márkahű vásárlók (értékük 4,08), és a nyugat-dunántúli régióban élők adták a legkisebb átlagértéket $(3,69)$ erre a kérdésre.

A harmadik állítás, miszerint a kitöltők inkább szeretnek új ízeket kipróbálni, az egész sokaságra nézve nem hozott egyértelmű eredményt.

A következő kérdésben a kitöltőknek a kolbászvásárlási döntést befolyásoló tényezőket kellett I-5 skálán értékelniük, mely eredménye a 3. táblázatban látható.
3. táblázat‡ A kolbászvásárlási döntést befolyásoló tényezők

$$
(\mathrm{N}=619)
$$

\begin{tabular}{|c|c|c|}
\hline Tényezők & Átlag & Szórás \\
\hline Korábbi elégedettség a termékkel kapcsolatban & 4,50 & 0,77 \\
\hline Kinézete, színe & 4,47 & 0,75 \\
\hline Összetétele, hozzávalói & $4, \mathrm{IO}$ & $\mathrm{I}, 07$ \\
\hline Rokonok, barátok ajánlása & 3,97 & 0,96 \\
\hline Ár & $3,3 \mathrm{I}$ & $\mathrm{I}, 09$ \\
\hline Márka, termék ismertsége & $3, \mathrm{II}$ & $\mathrm{I}, 26$ \\
\hline Kapcsolt termékek, akciók & 2,59 & $\mathrm{I}, 30$ \\
\hline
\end{tabular}

Megjegyzés: $A z$ eredményeket I-től 5 -ig terjedő végpontskálán értelmezzük, ahol I = Egyáltalán nem, $5=$ Teljes mértékben.

A legjobban befolyásoló tényezők az eredmények alapján a korábbi elégedettség a termékkel kapcsolatban, továbbá a termék kinézete, színe. Ezen tényezők 4,5 és 4,47-es átlagértékeket mutatnak, ami azt jelenti, hogy jelentősen befolyásolják a kolbászvásárlási döntést. A következő két helyen áll 4 körüli értékkel a „Termék összetétele, hozzávalói” és a „Rokonok, barátok ajánlása” tényező is, ami szintén meglehetősen nagy befolyással bír a kolbászvásárlásra vonatkozó döntési helyzetekben.

$\mathrm{A} z$ ár és márka, illetve termék ismertsége a középérték körül mozognak, viszont a magas szórási érték miatt nem mutatnak hiteles képet. A kapcsolt termékek és akciók kis mértékben befolyásolják a kolbászvásárlási döntést, bár ez az eredmény sem mérvadó az értékelés során. Viszont az egyértelműen megállapítható, hogy átlagosan vizsgálva ezek azok a tényezők, amelyekre kevesebb hangsúlyt fektetnek a fogyasztók a vásárlási döntéseik alkalmával.

A háttérváltozókkal történő összehasonlító elemzés alapján a férfiak és nők véleménye eltérő. A nők által megadott válaszok minden tényezőnél magasabb átlagértéket mutatnak, amiből az következik, hogy a nők jobban befolyásolhatók különböző tényezők által a vásárlásaik során, mint a férfiak. A legnagyobb eltérés a nemek között a termékek összetételére vonatkozóan mutatkozik meg, ahol a nők 4,25-ös, míg a férfiak mindössze 3,9I-es átlagértéket képviselnek.

Kor tekintetében a leginkább árérzékenyek a I 8-25 éves korosztály, míg a 46-55 évesek adták átlagosan a legalacsonyabb értéket erre a kérdésre. Az összetétel fontossága a legfiatalabb korosztályt illetően jelentősen alacsony $(3,87)$, míg a 36-45 és az 56-65 éves korosztályokat figyelve a legmagasabb (4,47 és 4,48 ez az érték).

\section{3+4+ Kolbászmárkák ismertsége és fogyasztásuk}

Nyitott kérdésként szerepelt a kérdőívben a megkérdezettek által legismertebb kolbászmárkák felsorolása. Az első hét leggyakrabban említett márka sorrendben: Gyulai, Csabai és Pick, Herz, Kaiser, Békési, Debreceni.

A következő kérdésben az előbb felsorolt márkák közül kellett a kitöltők által leginkább fogyasztott márkát leírni. Az első három helyen változatlanul a Gyulai, a Csabai, és a Pick állnak, viszont sokkal kevesebben fogyasztják, mint ismerik ezeket a márkákat a megkérdezettek közül. A Tóalmási és a Békési mint fogyasztott márkák még megjelennek az ábrán, az ezeknél kevesebbet említett márkák azonban már nem. 


\section{3+5+A kolbász táplálkozás-élettani szerepe}

A következő skálás kérdésben azt vizsgáltuk, hogy mennyire értenek egyet a kitöltők a táblázatban szereplő állításokkal. Ezek többnyire olyan megállapítások, amelyek a sertéshús- és kolbászfogyasztást egészségügyi oldalról támadják vagy védik, magukban foglalják a köznyelvben járatos szóbeszédeket és tévhiteket, illetve arra keresik a választ, hogy a kolbászfogyasztók mennyire vannak tisztában a kolbászhoz adott mesterséges anyagokkal, valamint állományjavítókkal, és mennyire befolyásolja ez őket vásárlásaik alkalmával. Az eredményeket a 4. táblázat tartalmazza.

4. táblázat: A kolbászfogyasztók véleményének mérése a kolbászfélék táplálkozás-élettani szerepére vonatkozóan $(\mathrm{N}=619)$

\begin{tabular}{|c|c|c|}
\hline Állitás & Átlag & Szórás \\
\hline $\begin{array}{l}\text { Nem hiszem, hogy bármi bajom lenne, ha megfelelő } \\
\text { minőségú kolbászt vásárolok. }\end{array}$ & 4,09 & $\mathrm{I}, \mathrm{I} 7$ \\
\hline $\begin{array}{l}\text { Nem érdekelnek azok a rémhírek, am } \\
\text { sertéshúsról (beleértve a kolbászt is) } \mathrm{m}\end{array}$ & 4,03 & $\mathrm{I}, 24$ \\
\hline $\begin{array}{l}\text { Mértékletes sertéshús- és sertéshúskészítmény- } \\
\text { fogyasztás mellett nem vagyunk kitéve szervrendszeri } \\
\text { megbetegedéseknek. }\end{array}$ & 3,67 & $\mathrm{I}, 29$ \\
\hline $\begin{array}{l}\text { Ha egy kolbász szóját vagy lisztet tartalmaz, } \\
\text { nem vásárolom meg. }\end{array}$ & 3,39 & $\mathrm{I}, 48$ \\
\hline $\begin{array}{l}\text { Ha egy kolbász tartósítószert, mesterséges színezéket } \\
\text { és ízfokozót tartalmaz, nem vásárolom meg. }\end{array}$ & $3,3 \mathrm{I}$ & $\mathrm{I}, 3 \mathrm{I}$ \\
\hline A sertéshús ('́gy a kolbász is) tele van zsírral. & 2,79 & $\mathrm{I}, \mathrm{I} 4$ \\
\hline $\begin{array}{l}\text { Nem szoktam figyelni, milyen mesterséges } \\
\text { adalékanyagot tartalmaz az általam vásárolt kolbász. }\end{array}$ & 2,70 & $\mathrm{I}, 45$ \\
\hline $\begin{array}{l}\text { A sertéshúsból készült termékek ('így a kolbász is) } \\
\text { magas koleszterinszintet eredményeznek. }\end{array}$ & 2,56 & $\mathrm{I}, \mathrm{I} 6$ \\
\hline $\begin{array}{l}\text { Igyekszem odafigyelni a felhívásokra és mértékkel } \\
\text { fogyasztani a sertéshústermékeket (beleértve a } \\
\text { kolbászt is). }\end{array}$ & $2,4 \mathrm{I}$ & $\mathrm{I}, 32$ \\
\hline $\begin{array}{l}\text { Nem érdekel, ha tartalmaz az általam vásárolt kolbász } \\
\text { mesterséges adalékanyagot, akkor is megveszem. }\end{array}$ & $2,4 \mathrm{I}$ & $\mathrm{I}, 3 \mathrm{I}$ \\
\hline $\begin{array}{l}\text { Aki fogyókúrázik, annak egyáltalán nem szabad } \\
\text { sertéshúskészítményt ennie. }\end{array}$ & $\mathrm{I}, 85$ & $\mathrm{I}, \mathrm{IO}$ \\
\hline A kolbász és a szalonna rákkeltő hatással bír. & $\mathrm{I}, 40$ & 0,78 \\
\hline
\end{tabular}

Megjegyzés: $\mathrm{A} z$ eredményeket I-től 5 -ig terjedő végpontskálán értelmezem, ahol I = Egyáltalán nem; 5 = Teljes mértékben.

Ahogyan az a táblázatból is látható, a válaszadók abban értettek egyet leginkább, hogy a megfelelő minőségű kolbász vásárlása nem okoz negatív egészségügyi következményeket. Emellett a kitöltők többsége nem foglalkozik a sertéshússal kapcsolatos negatív hírekkel sem. A következő állítások 3 körüli átlagértéke és az ehhez társuló magas szórási szint miatt nem értelmezhetők a sokaságra, ezért a háttérváltozókkal összevetett eredményeket közöljük. A kolbász lehetséges szója- és liszttartalmához való negatív hozzáállás a megkérdezettek életkorának növekedésével egyre erősödik. Régiónként vizsgálva is érdekes a különbség, hisz a Dél-Alföldön élők átlageredménye a legmagasabb $(3,85)$, míg a közép-dunántúli régió lakóié a legalacsonyabb $(2,80)$. Ugyanezen két régió között éles különbség figyelhető meg a tartósítószerre, mesterséges színezékre és ízfokozókra utaló állításnál.
A mesterséges adalékanyagokra legkevésbé a fiatalabb korosztály résztvevői kíváncsiak, és a kor előrehaladtával a tudatos fogyasztás valamelyest javulni látszik. A magas koleszterinszintre vonatkozó állítás alapján a nők kevésbé értenek egyet ezzel az állítással (értékük 2,47), míg a férfiak közül többen értékelték ezt a kérdést magasabbra (értékük 2,68). Ezek alapján megállapítható, hogy bár nem kiugróan magas a különbség a két nem között, a férfiak csekély mértékben, de jobban félnek az élelmiszerek okozta egészségügyi kockázatoktól, vagy tájékozottságukból fakadóan nagyobb jelentőséget tulajdonítanak a magas koleszterinszint kialakulásának.

Összességében megállapítható, hogy nem lehet általános következtetéseket levonni a kolbászfogyasztási szokásokkal kapcsolatban. Sajnos e táblázat adatai alapján nem jelenthető ki, hogy jól látható pozitív változás következik be, csupán egyes korcsoportokat vagy egy régióban élőket külön megfigyelve állítható, hogy a tudatos vásárlás és fogyasztás egyre jellemzőbb napjainkban.

\subsection{Kolbászvásárlás helyszínei, minőségi vásárlás}

A 4. ábrán a megkérdezettek által történő kolbászvásárlások leggyakoribb helyszínei láthatók.

4. ábra: Kolbászvásárlások leggyakoribb helyszínei, \% (N = 619)

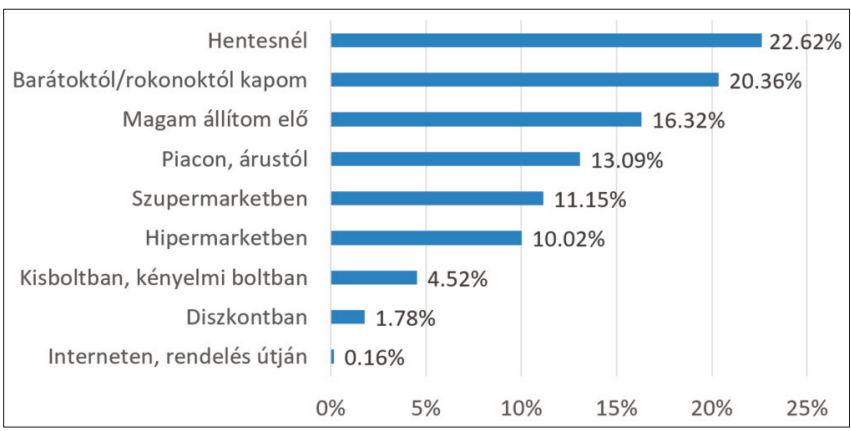

Az összes kitöltőt tekintve a legtöbben hentesnél vásárolnak, azonban nagyon magas az otthon elóállított és barátoktól/ rokonoktól kapott kolbászfélék aránya is. A legnépszerütlenebb vagy leginkább járatlan út a kitöltők kolbászvásárlásai során az internetes rendelés. A hentes mint a kolbászok beszerzésének leggyakoribb helyszíne az észak-alföldi és észak-magyarországi kitöltők körében a legmagasabb. A Dél-Alföldröl érkezett magasan a legtöbb válasz a „Magam állítom elő" és a „Barátoktól/rokonoktól kapom” kategóriákra.

Az 5. ábrán látható a havi átlagos kolbászfélékre kiadott összeg a kitöltők válaszai alapján.

\section{5. ábra : Havi átlagos kolbászfélékre kiadott összeg, \% (N = 619)}

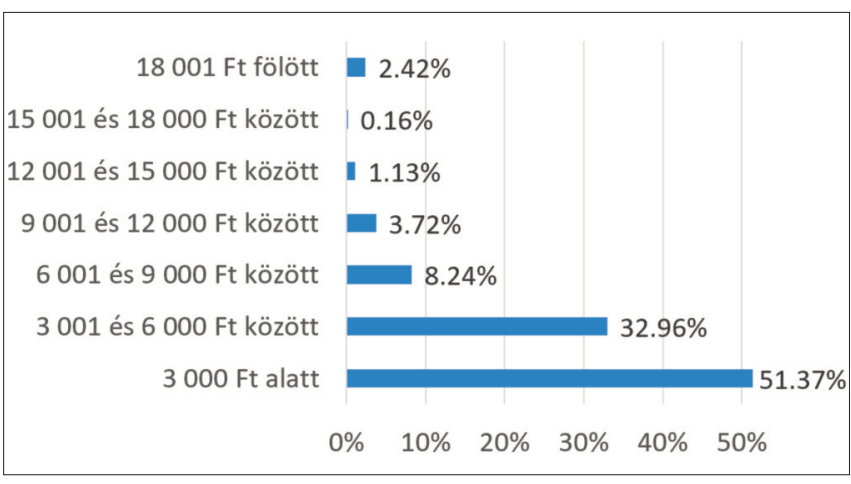


A válaszadók több mint fele 3 ooo Ft alatti összeget költ havonta kolbászfélékre, 32,9\%-uk pedig 3 oo I és 6 ooo Ft közötti összeget. A háttérváltozókkal végzett elemzések alapján megállapítható, hogy a nők nagyobb részben jelölték a 3 ooo Ft alatti kategóriát a férfiakkal szemben, míg a többi, magasabb összegre utaló kategóriában a férfiak vannak nagyobb arányban (kivéve a I2 000 Ft-tól I8 $000 \mathrm{Ft}$-ig tartó intervallumot, ahol értékük azonos). Ezek alapján a férfiak általában magasabb összeget költenek kolbászvásárlásaik során, mint a nők.

A következő kérdésben, miszerint a válaszadók hajlandóak lennének-e magasabb árat fizetni egy jobb minőségű termékért, a megkérdezettek 94,6\%-a válaszolt igennel, azaz hogy hajlandó lenne drágább terméket vásárolni, ha ahhoz magasabb minőség társulna.

\section{3+7* Médiahasználati szokások a kolbászokkal kapcsolatban}

Az 5. táblázatban a leggyakoribb információs csatornák láthatók, valamint három kérdés ezekre vonatkozóan. A válaszadóknak a jelenleg igénybe vett, általuk leghitelesebbnek vélt és jövőbeli információszerzési csatornák közül kellett a legfontosabbat bejelölni adott kérdésre vonatkozólag. Ez alapján látható, hogy nagyon erős a szájreklám a kolbászok piacán, a válaszadók több mint fele jelölte a családtagokat és barátokat, ismerősöket a leggyakoribb információforrásnak. A kereszttáblás elemzés során kiderült, hogy a férfiak nagyobb arányban kérik ki barátaik, ismerőseik, a nők pedig családtagjaik véleményét. Míg a reklámokra és reklámújságokra a nők nyitottabbak, addig az internetes keresőoldalakat férfiak használják gyakrabban kolbászokkal kapcsolatos információszerzéshez. Régiónként vizsgálva a családtagok véleménye a Dél-Alföldön és DélDunántúlon a legerősebb, a fesztiválokon való tájékozódás pedig az Észak-Alföldön élők számára a legmérvadóbb.

$\mathrm{Az}$ információforrások hitelességét illetően ugyancsak a családtagok és a barátok, ismerősök bizonyultak a legerősebbnek, bár kisebb százalékban, mint az előző kérdésnél. Ezt követi egyenlő százalékban a „Dietetikus / orvos” és a „Szakmai lapok, könyvek”, habár más-más témakörben adhatnak tájékoztatást. A többi kategóriához képest jelentősebb százalékkal szerepelteti magát a „Fesztiválok, kapcsolódó rendezvények” kategória mint leghitelesebb információforrás a kolbászokkal kapcsolatban.

Arra a kérdésre, hogy „A jövőben honnan szeretne leginkább informálódni?”, a legtöbb válasz ismét a „Családtagok”' és a „Barátok, ismerősök" kategóriában érkezett, bár az előbbire adott válaszok száma ismét csökkenést mutatott. Ezzel ellentétben nagy növekedést mutat a korábbi kérdésekre adott válaszokhoz képest azon kitöltők száma, akik a jövőben fesztiválokon, és kolbászhoz kapcsolódó rendezvényeken, valamint internetes keresőoldalak vagy közösségi oldalak által szeretnének tájékozódni.

\section{KÖVETKEZTETÉSEK, JAVASLATOK}

Kutatásunk során a kolbászfogyasztási szokásokat vizsgálva, Magyarországra vetítve, a következő megállapításokat tettük.

Magyarország lakosságának jelentős része fogyaszt kolbászt, ezen belül a férfiak és az idősebb korosztály nagyobb gyakorisággal. A csípős és a csemege kolbász kedveltsége szinte megegyezik, a

5, táblázat: A kolbászokkal kapcsolatos tájékozódás során használt, hitelesnek vélt és a jövőben használni kívánt információforrások $(\mathrm{N}=619)$

\begin{tabular}{|c|c|c|c|c|c|c|c|c|}
\hline \multicolumn{3}{|l|}{ Igénybe vett forrás } & \multicolumn{3}{|l|}{ Hiteles forrás } & \multicolumn{3}{|c|}{ Jövöben használni kívánt forrás } \\
\hline Információforrás & $F_{o ̈}^{\prime \prime}$ & $\%$ & Információforrás & Fö & $\%$ & Információforrás & $F_{o ̈}^{\prime \prime}$ & $\%$ \\
\hline Családtagok & 227 & 36,7 & Családtagok & I94 & $3 \mathrm{I}, 3$ & Családtagok & I67 & 27,0 \\
\hline Barátok, ismerősök & I83 & 29,6 & Barátok, ismerősök & I34 & $2 \mathrm{I}, 7$ & Barátok, ismerősök & 149 & $24, I$ \\
\hline Reklámok, reklámújságok & 43 & 7,0 & Dietetikus/orvos & 78 & I 2,6 & $\begin{array}{l}\text { Fesztiválok, kapcsolódó ren- } \\
\text { dezvények }\end{array}$ & 58 & 9,4 \\
\hline Egyéb & 37 & 6,0 & Szakmai lapok, könyvek & 78 & I 2,6 & $\begin{array}{l}\text { Internetes keresőoldalak } \\
\text { (Google })\end{array}$ & 46 & 7,4 \\
\hline $\begin{array}{l}\text { Fesztiválok, kapcsolódó ren- } \\
\text { dezvények }\end{array}$ & 34 & 5,5 & $\begin{array}{c}\text { Fesztiválok, kapcsolódó ren- } \\
\text { dezvények }\end{array}$ & 43 & 7,0 & Szakmai lapok, könyvek & $4 \mathrm{I}$ & 6,6 \\
\hline $\begin{array}{l}\text { Internetes keresőoldalak } \\
\text { (Google) }\end{array}$ & 33 & 5,3 & Egyéb & 26 & 4,2 & Dietetikus/orvos & 35 & 5,7 \\
\hline $\begin{array}{c}\text { Közösségi oldalak (Facebook, } \\
\text { Twitter) }\end{array}$ & I 2 & $\mathrm{I}, 9$ & $\begin{array}{c}\text { Internetes keresőoldalak } \\
\text { (Google) }\end{array}$ & I6 & 2,6 & $\begin{array}{c}\text { Közösségi oldalak (Facebook, } \\
\text { Twitter) }\end{array}$ & 33 & 5,3 \\
\hline Blogok & 8 & $\mathrm{I}, 3$ & Blogok & 8 & $\mathrm{I}, 3$ & Reklámok, reklámújságok & 28 & 4,5 \\
\hline Országos televízió & 7 & $\mathrm{I}, \mathrm{I}$ & Helyi napilap & 7 & $\mathrm{I}, \mathrm{I}$ & Országos televízió & 9 & $\mathrm{I}, 5$ \\
\hline Dietetikus/orvos & 5 & 0,8 & Országos televízió & 6 & $\mathrm{I}, \mathrm{O}$ & Helyi napilap & 7 & $\mathrm{I}, \mathrm{I}$ \\
\hline Internetes hírlevelek & 5 & 0,8 & Országos rádió & 5 & 0,8 & Internetes hírlevelek & 5 & 0,8 \\
\hline Országos napilap & 5 & 0,8 & Helyi rádió & 3 & 0,5 & Országos rádió & 5 & 0,8 \\
\hline Helyi napilap & 4 & 0,7 & Országos napilap & 3 & 0,5 & Országos napilap & 3 & 0,5 \\
\hline Országos rádió & 3 & 0,5 & Helyi televízió & 2 & 0,3 & Helyi rádió & 2 & 0,3 \\
\hline Helyi rádió & 2 & 0,3 & Internetes hírlevelek & 2 & 0,3 & Blogok & I & 0,2 \\
\hline Helyi televízió & I & 0,2 & $\begin{array}{c}\text { Közösségi oldalak (Facebook, } \\
\text { Twitter) }\end{array}$ & 2 & 0,3 & Helyi televízió & I & 0,2 \\
\hline
\end{tabular}


csemege kolbászok a nők által kedveltebbek, a csípős kolbász pedig a Dél-Alföldön magasan a legkedveltebb.

Általánosságban elmondható, hogy a kolbászvásárlók lojálisak egy korábban megkedvelt termékhez, emellett (de ritkábban) szívesen kóstolnak meg nekik tetsző más termékeket. A nők jobban ragaszkodnak egy már bevált termékhez, mint a férfiak, továbbá a fiatalabbak szívesebben kísérleteznek a kolbászok piacán.

A kolbászvásárlási döntést legjobban a termékkel kapcsolatos korábbi elégedettség, valamint a termék kinézete, színe befolyásolja, valamint jelentős mértékben számít a termék összetétele és hozzávalói. A kolbászvásárlási döntéseket az ár, a márka, termékek ismertsége és a kapcsolt termékek, akciók kevésbé befolyásolják. Ezen felül a nőket lényegesen jobban foglalkoztatja a termék összetétele, mint a férfiakat.

A kolbászmárkák közül a Gyulai, a Csabai és a Pick a legismertebb. A fogyasztók többnyire nincsenek tisztában a kolbászok és szalámik közötti különbséggel a termékek kinézetét illetően.

A fogyasztók többnyire egyetértenek azzal, hogy a megfelelő minőségű kolbász nem jelent veszélyt az emberi szervezetre. Nagy a megoszlás a fogyasztók között azzal kapcsolatban, hogy figyelik-e, illetve megvásárolják-e a mesterséges adalékanyagokat tartalmazó termékeket. A kolbászfogyasztók nem értenek egyet a kolbászra vonatkozó rémhírekkel és negatív sztereotípiákkal. A kutatás azt az eredményt hozta, hogy a Dél-Alföldön élők a legtudatosabb fogyasztók a kolbászvásárlás területén.

A kolbászvásárlók leggyakrabban hentesnél vásárolnak, kisebb mértékben piacon árustól szerzik be a kolbászféléket. A Dél-Alföldön élők többnyire maguk állítják elő vagy barátoktól/rokonoktól kapják a kolbászféléket. A kolbászfogyasztók 94,7\%-ánál megfigyelhető magasabb fizetési hajlandóság a jobb minőség ellenében.

Végezetuil pedig a kolbászok piacán a szájreklám nagyon nagy jelentőséggel bír, sokkal fontosabb a termékek ajánlása rokonok, barátok és ismerősök által, mint a többi igénybe vett információforrás.

Megjelent hazánkban a tudatos fogyasztás, egyre nagyobb mértékben figyelik a vásárlók a termékek összetételét, viszont jelentősen megoszlik azok aránya, akik foglalkoznak a termékekhez hozzáadott mesterséges adalékanyagokkal és állományjavítókkal.

A kolbászvásárlással kapcsolatos tudatosság a kutatásunk alapján a Dél-Alföldre jellemző a leginkább, és a Dunántúlon - a kevésbé jelentős kolbászkultúra miatt - a legkevésbé jellemző.

Javaslatainkkal főként azokat a piaci szereplőket kívánjuk segíteni, akik kolbászkészítéssel és -értékesítéssel foglalkoznak.

Magyarországnak elsősorban az egészségtudatos fogyasztás területén kellene fejlődnie. Mivel az Alföldön - jelentős kolbászkultúrája miatt - a fogyasztók tudatossága erős, főként a Dunántúlra volna szükséges fókuszálni. Valamilyen módon meg kellene mutatni az ország azon részén élőknek is az alföldi termékek széles választékát, a hungarikum kolbászok történelmi múltját és a kolbászkultúrát.

Mivel az internet nagyon sok információ közlésére lehetőséget ad, és a fogyasztók nagy része használja, a vállalkozásoknak élniük kell ezzel a lehetőséggel. Javasoljuk az erősebb online jelenlétet a vállalkozásoknak (blog, weboldal, Facebook-oldal, Youtube-csatorna stb.) és hogy ezt minél egyedibb, kreatívabb módon tegyék, pozícionálva magukat a vásárlók számára.

Fontos üzenet továbbá, hogy azok a piaci szereplők, akik hosszú távon tudják tartani az általuk kínált termék minőségét, megbízhatóbbak lesznek a fogyasztók körében, és lehetőségük van arra, hogy a szájreklám útján „terjedjenek”. Javaslataink között szerepel tehát, hogy a kínálati oldal szereplői fontos (ha nem a legfontosabb) szerepet tulajdonítsanak a minőség megtartásának.

\section{5. ÖSSZEFOGLALÁS}

A felmérés célja az volt, hogy szélesebb perspektívát kapjunk a magyarországi lakosok kolbászfogyasztási szokásairól, segítve ezzel azoknak a piaci szereplőknek a munkáját, akik kolbászkészítéssel és -értékesítéssel foglalkoznak, és szeretnék megismerni a potenciális vevőik igényeit, véleményét, döntési kritériumait. A kutatás során online kérdőíves megkérdezést végeztünk, melyben 690 fó vett részt. A kutatás során tett legfontosabb megállapítások közt szerepel, hogy a magyar lakosság nagy része rendszeresen fogyaszt kolbászt, főként a hagyományos csemege és csípős ízesítést választva. A vásárlási döntést leginkább a korábbi elégedettség, valamint a termék kinézete, színe befolyásolja, valamint felfedezhető a lojalitás a megszokott termékek iránt. A tudatos fogyasztás is előtérbe kerül, fontos szerep jut a minőség kérdésének, viszont nagy a szórás a nemek és különböző korcsoportok között is. Emellett a kutatás kitér a kolbászvásárlás körülményeire és a termékkel kapcsolatos médiahasználati szokások feltérképezésére is.

\section{IRODALOM}

(I) Bíró, Gy. (2007). Táplálkozási és egészségi állítások az élelmiszereken a fogyasztók és az elóállítók érdekében. In Magyar Táplálkozástudományi Társaság XXXII. Vándorgyűlése. Kecskemét, 2007. október I8-20. Absztraktkötet.

(2) Gál, T., Soós, M. \& Szakály, Z. (20I7). Egészségtudatos táplálkozással kapcsolatos fogyasztói insight-ok feltárása netnográfiával - Esettanulmány. Vezetéstudomány, 48(4), 46-54. doi: I0.14267/veztud.2017.04.07

(3) IPSOS. (2013). Kutatási Report a Sertéshús Fogyasztói szokásokról. Letöltés dátuma: 2016. 09. Io. forrás: IPSOS Marketing:

http://www.szermgrt.hu/uploads/ckfinder/userfiles/files/Ipsos Kutatási Report Sertéshús Fogyasztói Szokásokról.pdf

(4) Kozák, Á. (2009). Táplálkozás, fogyasztás és életmód a rendszerváltás utáni Magyarországon. Élelmiszer, Táplálkozás és Marketing, 6(I-2), I9-23.

(5) KSH. (20I6). A háztartások fogyasztása 2015. Letöltés dátuma: 2016. 09. 10., forrás: Központi Statisztikai Hivatal: https://www.ksh.hu/docs/hun/xftp/stattukor/haztfogy/haztfogy I5I2.pdf

(6) Népszava. (2016. 09 I6). Sokkolta a világot a WHO-jelentés. Tényleg rákkeltő a vörös hús? Letöltve: 20I6. 09. I6., forrás: http://nepszava.hu/cikk/I074465-sokkolta-a-vilagot-a-whojelentes---tenyleg-rakkelto-a-voros-hus

(7) Soós, M. \& Szakály, Z. (2013). Testtömeg-menedzselési attitűdök kvalitatív és kvantitatív vizsgálata Magyarországon. Élelmiszer, Táplálkozás és Marketing, 9(2), 29-32.

(8) Szakács, Zs. (2012). A márkázott húskészítmények fogyasztása hazánkban PhD-értekezés. Szent István Egyetem. Gödöllő. Letöltés dátuma: 2016. 09. I5., forrás: https://szie.hu//file/tti/archivum/Szakacs_Zsolt_tezis.pdf

(9) Szakály, S. (2004). Táplálozási dilemmák és az élelmiszerek fejlesztésének világstratégiai irányai. Élelmiszer, Táplálkozás és Marketing, I(I-2), I $5-24$.

(Io) Szakály, Z. (2008). Trendek és tendenciák a funkcionális élelmiszerek piacán: mit vár el a hazai fogyasztó? Élelmiszer, Táplálkozás és Marketing, 5(2-3), 3-I I.

(II) Szente, V. (20I0). Egyes hagyományos és tájjellegü magyar termékek és -élelmiszerek táplálkozási előnyei, kiemelt példákkal. 
In Szakály, Z., Pallóné, I. \& Nábrádi, A. (20ı s szerk.). Marketing a hagyományos tájjellegü élelmiszerek piacán. (pp. 37-42).

Kaposvár: Kaposvári Egyetem Gazdaságtudományi Kar.

(I2) Várhegyi, J-né \& Várhegyi, J. (2007). A marhahús megítélése humán egészségügyi szempontból. Irodalmi Összefoglaló. Herceghalom: Állattenyésztési és takarmányozási Kutatóintézet. Letöltés dátuma: 20I6. 09. 20., forrás:

http://miau.gau.hu/osiris/content/docs/atk/varhegyine_dec.html (13) Vida, V. (20I2). A sertéshús fogyasztói megítélése és piaci helyzete Magyarországon. PhD-értekezés. Debrecen: Debreceni Egyetem. Letöltés dátuma: 2016. 9. I2., forrás:

http://www.science.unideb.hu/media/document/I2062I_vidavik toria.pdf
(I4) Zsarnóczay, G. (20I I). Nitritmennyiségek hatásának vizsgálata húskészítményekben. $\mathrm{PhD}$-értekezés. Budapest: Élelmiszertudományi Doktori Iskola.

(I5) Zsarnóczay, G. (2009). A vöröshúsok szerepe a táplálkozásban. Élelmiszer, Táplálkozás és Marketing, 6(I-2), 5 I-58.

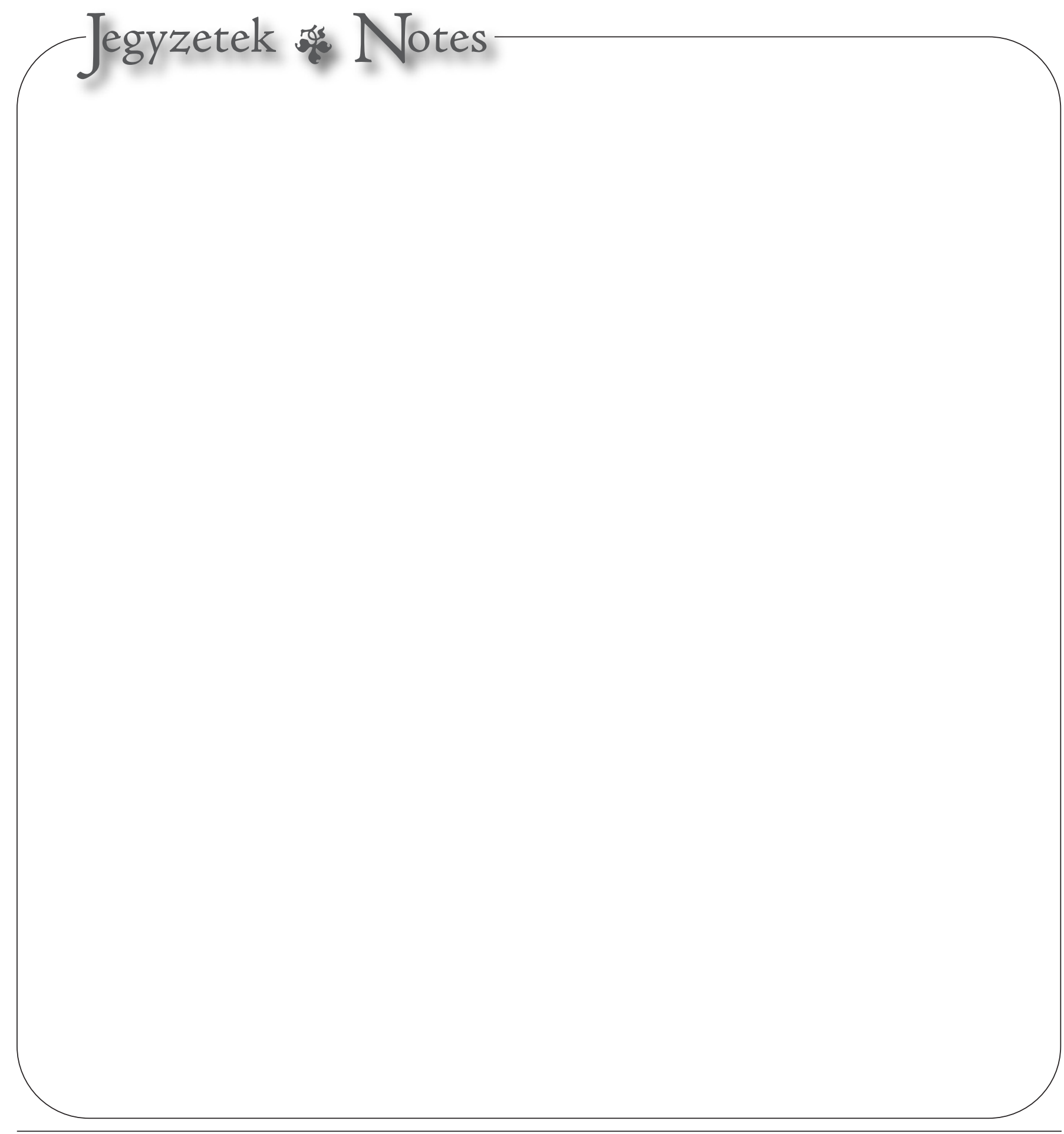

